\title{
25 Engendering agricultural transformation
}

\author{
Joyce Chitja and Gabisile Mkhize
}

\section{Conceptualizing gender and the engendering of agriculture in Southern Africa}

The definition and meaning of gender are often misunderstood. Some equate gender to only women's issues and view it as a binary category of sex, thus undermining gender as a social construct (Mkhize, 2015). Embedded in our everyday practices and activities, gender is socially constructed and performed and exists in continuum (Lorber and Farrell, 1991). Gender is part of peoples' and communities' daily existence and reflects the ways the world is organized. Further, Krieger (2003) views gender as a social construct that is enforced through culture-bound conventions, roles and behaviours for relations between women and men and boys and girls. In Africa, socially constructed gender roles and patterns often vary across a continuum within and across societies in relation to social divisions premised on unequal gendered power and authority (Mkhize, 2015; Krieger, 2003; Lorber and Farrell, 1991). Fixed gender roles located within feminine and masculine gender schemas produce gender inequalities. For instance, sexist and patriarchal beliefs and cultural practices attach subordinate gender roles to women such as domestication, nurturing and dependency while attaching superior gender roles to men exemplified by leadership, ownership and independence (Mkhize and Njawala, 2016). Such sexist and patriarchal normative gender role assignment reinforces major gender inequalities in societal structures and practices. In gendered agricultural contexts, control and access to agricultural production resources are therefore by default men's forte, despite women being the majority in agricultural production (FAO, 2009).

Rolleri (2013) further elaborates that in many communities and/or societies throughout the world, including Southern Africa, a condition of gender inequality exists where women and the feminine are often devalued, and men and masculine traits are favoured. Here men often possess more power in decision making in personal, community and political arenas, while women's needs and interests are undermined. In most African societies, the learned behaviour leaves women more vulnerable to food insecurity, health and wellbeing (Thamaga-Chitja, 2012). Consequently, these socially constructed realities foster inequalities prevalent in socioeconomic systems, especially that of 
agriculture. Debatably in Africa and the Southern African Development Community (SADC), women are said to be at the centre of agricultural while in fact they are at the periphery where men mostly own the land and the majority of agricultural socioeconomic assets (Doss et al., 2015). Women remain the invisible stakeholders in agricultural platforms (Whatmore, 2016; Ogunlela and Mukhtar, 2009). Africa is thus seen to be at the bottom-end of the gender equality spectrum of gender inequality practices. Researchers who have worked in African societies have reported on the disenfranchisement and unequal treatment of women in agriculture and development (Olatunji, 2013; Meinzen-Dick et al, 2011).

In the 1970s, feminist scholars, activists and professionals concerned about women's interests decided to design women-centred development approaches such as Women in Development (WID), Women and Development (WAD) and Gender and Development (GAD). These approaches were aimed at pressuring international agencies and developing countries' governments, including those of Southern Africa, to incorporate women in development policy, planning and practice (Bhavnani et al., 2003; Rai, 2002; Moser, 1993). Thus, WID, WAD and GAD seek to bring women of developing countries closer into socioeconomic development processes including in agriculture, in their communities and societies. GAD focuses on empowering women as leaders. WID, WAD and GAD assume that women are important socioeconomic contributors in many societies of the South, and they seek a more sustainable and people-focused approach (Sen and Grown, 1987; Rai, 2002). In trying to address such gender-based inequalities, major actions and plans were developed, and many African countries committed to implementing those plans. For instance, Millennium Development Goal 3 and now Sustainable Development Goal 5 emphasize promotion of gender equality and women's empowerment. In addition to international gender debates, attempts to eradicate gender inequalities, ending gender-based discriminations is integral in the SADC's policies and agendas. In reinforcing a transformative agenda, the SADC (2018) gender policy promotes gender equity in all regions' developmental strategies and practices.

However, despite SADC's intervention, most women in Southern Africa continue to lag behind men in the development process including in agriculture and thus delaying development outcomes that can be achieved through gender inclusivity and collaboration. Just like in most African societies, in Southern African communities land is key to community development and the agriculture for farming. It is clear that women remain invisible in agriculture and land-based livelihood development. Such gender imbalances are not adequately addressed; hence, this chapter envisions engendering of agriculture as a viable and important tenet in agricultural transformation in SADC. Doss et al. (2015) view narratives of women's land ownership in Africa as purely a myth, since most men, irrespective of racial-ethnicities, own and control the land and its means of production and profit. It is within this context that the engendering agriculture and its related value chains is critical. This is no different in 
countries in Southern Africa, as attested by Honorable Gertrude Mongella of Tanzania when she said, "most men in Africa went to school because their mothers were farmers, [who] are the very same women that maintain the continent" (Hall and Osario, 2004).

\section{Non-transformative gendered agricultural contexts}

Currently and historically smallholder farmers, particularly women who dominate rural agriculture, reside in rural Southern Africa within communities that are socioeconomically less endowed. Rural communities in Southern Africa are resource-limited from a macro- and micro-structural point of view reflected in financial, physical, human and social resources. The transformation of these resources into sustainable livelihoods is only possible if there is gender parity, harmony, partnership and an environment that yields a conducive environment to power sharing. Constraints such as low production and productivity, poor access to inputs, credit and poor access to land characterize smallholder farming in Southern Africa (van Schalkwyk et al., 2012). Land is central in the construction of gender and power relations in such communities where rights to land access should be protected (Hall and Osorio, 2014). In spite of women dominating production, they face practice and policy-induced barriers to land access and ownership.

Women farmers' lived experiences of navigating laws and practices that negatively affect their efforts to access land in order to improve their livelihoods and household food security are important in policymaking, yet such women or their voices rarely are present when these policies are designed. As observed by many researchers, including Thamaga-Chitja et al. (2010), Chitja et al. (2016), Hall and Osorio (2014), women often have weaker customary and statutory rights and have barriers to participating in decision-making processes. In most of Southern Africa, including South Africa, the dichotomy of legislative framework and the cultural practices yields a contradictory policy and practice environment where land rights are concerned. In South Africa, for example, despite the clear policy on equal rights of access to all people in South Africa in the constitution, women in rural areas are negatively affected by the reality of this dichotomy, where traditional courts and the communities actuate biased and socially embedded gendered laws and practices that wield a different reality (Odeny, 2013; Ntsebeza, 2004). In most Traditional Authorities in South Africa and similar cultural contexts in Africa and SADC countries (e.g., Malawi, Zimbabwe, Lesotho and Tanzania), women are often viewed as minors (Thamaga-Chitja et al., 2010; Tripp et al., 2008), lacking access to land because of patriarchal, cultural and religious embedded norms, even where progressive statutory law exists. Evidently, cultural practices that are steeped in patriarchy tend to recognize males as heads of households and land access rights holders more than women regardless of women's dominance in the production of food in rural South Africa and as household heads in over $60 \%$ of households (Schatz, 2011). Mechanisms to mitigate this are key to protect the most 
vulnerable women. Agriculture acts as a key survival strategy for the majority of underdeveloped and developing countries globally to conquer food and nutrition insecurities. A study by (van Arendonk, 2015) found that the position of agriculture within the economy seems more important in developing countries and less important in developed countries, however different gender associated challenges have shown to be among the factors limiting maximum potential and capabilities of production.

Agriculture and agriculture related land rights have been mostly linked with the masculine practices in relation to land rights where women are mostly associated with in-house related activities. Such beliefs have limited women's access to agricultural land, knowledge and skills, which could potentially increase food production for household food and nutrition security. In Southern Africa, women commonly own less land, and what they own is most often of lower quality compared to the land possessed by men (Adeniyi, 2010). Women in Africa, including Southern Africa, only own 1\% of the land and have to cope with limited access to supporting inputs such as financial and mechanical assets (Adeniyi, 2010). Given the point that women are key players towards alleviating poverty and food insecurity at household level, gender inequality and limited access to agricultural inputs in Southern Africa limits their potential. Addressing gender inequality in agriculture can possibly improve food production, reducing household food and nutrition insecurity. However, apparent inadequate appreciation and understanding of the negative role of related "custom" and "culture" among political leaders and civil servants, including extension services and TAs, impede progress and investment.

A study by Diiro et al., 2018 showed that between male managed and female managed agricultural plots, there is a significant improvement in productivity when the women managed the plots. These findings provide evidence that women's empowerment in agriculture positively contributes to reducing the gender gap in agricultural productivity and improving, specifically, productivity from farms managed by women (Diiro et al., 2018). Efforts to increase women's participation in poverty alleviation projects should encourage women's capacity building by providing incentives and opportunities that enable them to increase their competitive potential in their enterprise and policymaking. Policies that protect rights of and access for women to education and encourage them to complete at least a high school degree will help increase opportunities for women to participate in poverty alleviation (Nkemnyi et al., 2017). Given the beliefs and cultural practices, and understanding that the majority of rural African communities possess them, changing gender inequality in agriculture is challenging. To address this issue, the involvement of government and nongovernmental organizations (NGO) focused on farmer development using empowerment and agency building approaches is important. However, government extension and NGOs will need to be well endowed in participatory approaches that aim and bring a paradigm shift. Periodic feedback to policymakers is critical during this process. Agricultural funding should be directed equally be directed towards resources for women farmers and such actions are 
likely to increase their productivity and household food security and welfare. Some of these funds could be used to train both men and women with technical and "soft" skills and knowledge required to adapt and thrive in a changing business, sociocultural and climate environment. Formulation of gendered initiatives that enable women with improved access to land and markets is critical for real change.

\section{Gender equity policies, processes and transformation}

As discussed, in many African and SADC countries, including South Africa, statutory and cultural laws and practices clash spectacularly, leaving women negatively impacted with limited access to agriculturally productive land (Agarwal, 1994; Thamaga-Chitja and Morojele, 2014). The authors therefore argue for gender equity policies and processes in agricultural development context to be revisited to be more gender inclusive. Moreover, cultural and religious practices that prevails despite progressive statutory law require capacity and capability of extension agents and communities empowered in change management and creating new, yet positive, realities.

Gender policy can be strengthened by promoting gender mainstreaming and gender machineries in all SADC societies to promote the implementation of gender equality in farming. SADC promotes gender equity as a fundamental human right pivotal to the regional development initiatives (SADC Gender Policy, 2005). Thus, promoting gender centred development policies is significant for poverty eradication and family sustainability not only in SADC but in Africa at large. In addition, Technical Centre for Agricultural and Rural Cooperation (CTA) argues that women's transformation in agriculture needs to be tracked through and index, the agribusiness access Index (Adedeji et al., 2019). There should be a creation of a gender machinery, being correctly tooled personnel in extension research policy and community to facilitate and monitor gender equal participation in agricultural development projects, including farming.

Prior to democracy, Southern African legislation access to human and land rights only for the minority. Achieving equality was among the main priorities aimed to be achieved after obtaining democracy. The democratic South African government after 1994 began to make laws and implement programmes aiming to dismantle inequality. Similarly, countries in the southern Africa region countries have had attempts at a policy level to correct this, but evidence of change at a ground level is thin. For example, the 2008 SADC policy on gender and development prioritizes some substantive targets for achieving gender equality by 2015 . Since agriculture is the main domain for fighting food insecurity, land reform and redistribution was within the primary of those programmes. Although the set of plans and acts to dismantle inequality were put into ideas and plans, it appears that the majority of actions addressed male related inequalities, resulting in woman getting least of economic activities, infrastructure and skill straining. SADC (2018) notes that various gender inclusive legislations are 
in existence in its regions, mostly evident in their gender policies that promote gender machinery, gender mainstreaming and women's empowerment. However, despite this, gender-orientated strategies and attempts, representation and participation of women in farming land ownership, decision making and profit making remain marginalized and inferior to that of men who continue to fully control and own the land, its usage and its profits. The chapter argues for the engendering of agricultural transformation policies and programmes, and the disabling of socially imbedded roles of women which need to be disrupted to bring about equity yielding transformation.

The following framework, in Table 25.1, puts forward key issues, policy and desired change ignitors. It includes the Centre for Agricultural and

Table 25.1 Key factors in gender policy change

\begin{tabular}{|c|c|c|c|}
\hline Wabi-indicator & Policy action & Ignitors & Who is responsible \\
\hline Access to land & $\begin{array}{l}\text { Evaluate existing } \\
\text { policies and } \\
\text { programmes for } \\
\text { gender equity, } \\
\text { rewrite policy and } \\
\text { establish effective } \\
\text { programmes }\end{array}$ & $\begin{array}{l}\text { Implement agriculture } \\
\text { and gender inclusive } \\
\text { policy; train, equip and } \\
\text { skill all personnel }\end{array}$ & $\begin{array}{l}\text { Government, } \\
\text { cultural/ } \\
\text { traditional } \\
\text { authorities, } \\
\text { farmers }\end{array}$ \\
\hline $\begin{array}{l}\text { Finance and } \\
\text { Investment }\end{array}$ & $\begin{array}{l}\text { Evaluate the level of } \\
\text { access to finance } \\
\text { and tailor make } \\
\text { policy }\end{array}$ & $\begin{array}{l}\text { Facilitate equal access } \\
\text { and appropriate } \\
\text { finance and investment } \\
\text { portfolios }\end{array}$ & $\begin{array}{l}\text { Government, } \\
\text { NGOs, farmers }\end{array}$ \\
\hline Skills Support & $\begin{array}{l}\text { Gender inclusive } \\
\text { stakeholders to } \\
\text { identify the needs }\end{array}$ & $\begin{array}{l}\text { Continual appropriate } \\
\text { training and retraining } \\
\text { programmes }\end{array}$ & $\begin{array}{l}\text { Extension services } \\
\text { and NGOs, }\end{array}$ \\
\hline $\begin{array}{l}\text { Networking } \\
\text { and Capacity } \\
\text { Development }\end{array}$ & $\begin{array}{l}\text { Assess the availability } \\
\text { of educational and } \\
\text { technical extension } \\
\text { resources for } \\
\text { women }\end{array}$ & $\begin{array}{l}\text { Establish skills- based } \\
\text { programmes for } \\
\text { women }\end{array}$ & $\begin{array}{c}\text { Extension services, } \\
\text { NGOs, farmers }\end{array}$ \\
\hline $\begin{array}{c}\text { Knowledge and } \\
\text { Technology }\end{array}$ & $\begin{array}{l}\text { Analyze existence and } \\
\text { access of efficient } \\
\text { and labour-saving } \\
\text { tools and equipment }\end{array}$ & $\begin{array}{l}\text { Implement updated } \\
\text { technical training, } \\
\text { using accessible state- } \\
\text { of-the-art technology }\end{array}$ & $\begin{array}{l}\text { Extension services, } \\
\text { NGOs, private } \\
\text { sector }\end{array}$ \\
\hline $\begin{array}{l}\text { Overcoming } \\
\text { Embedded } \\
\text { Sociocultural } \\
\text { Practices and } \\
\text { Belief }\end{array}$ & $\begin{array}{l}\text { Assess the belief and } \\
\text { practices in each } \\
\text { context and align to } \\
\text { equality and fairness }\end{array}$ & $\begin{array}{l}\text { Capacitate extension, } \\
\text { lead farmers and NGO } \\
\text { personnel as change } \\
\text { agents; raise awareness } \\
\text { and campaigns on } \\
\text { gender inequalities and } \\
\text { inclusivity }\end{array}$ & $\begin{array}{l}\text { Government, } \\
\text { extension } \\
\text { services, } \\
\text { cultural/social } \\
\text { bodies, farmers }\end{array}$ \\
\hline $\begin{array}{l}\text { Appropriate } \\
\text { Recognition } \\
\text { of Women in } \\
\text { Society }\end{array}$ & $\begin{array}{l}\text { Assess and highlight } \\
\text { women's } \\
\text { contributions } \\
\text { to agriculture } \\
\text { and publicize at } \\
\text { platforms }\end{array}$ & $\begin{array}{l}\text { Implement practical } \\
\text { and proportional } \\
\text { participation of } \\
\text { women in agricultural } \\
\text { programmes, practices } \\
\text { and policies }\end{array}$ & $\begin{array}{l}\text { Government, } \\
\text { extension } \\
\text { services, } \\
\text { cultural/social } \\
\text { bodies, farmers, } \\
\text { media }\end{array}$ \\
\hline
\end{tabular}


Rural Cooperation (CTA) developed index named Women Agribusiness Index Indicator (WABI)

Land access, finance and investment, skills, networking and capacity development are all elements that are critical for addressing gender equity in transforming agriculture. However, the correct environment that is natured by skilled and capacitated extension personnel, NGO and lead farmers to confront backward cultural practices that impede transformation based on biased gender practices is critical.

\section{Conclusions}

Transformation is a process. A solution for engendered change may lie in a process where power between men and women is addressed through engagement, negotiation, learning and change. This should result in agency for both men and women. Stakeholders also need gender empowerment in this paradigm shift, e.g., extension services, NGOs, traditional leaders, lead farmers, community structures, input suppliers, etc., because of their role in farmer development. Empowering women for greater access to resources, knowledge and support is important. This process requires capacitated personnel functioning as a gender machinery alongside legislation, policies and practices to bring forth the desired change. However, changing the environment that houses the social and cultural constructs of women's position in communities by overcoming female stereotypes and traditional gender roles in rural communities is key and will have a positive result. This should yield better access and a more equal position in society for women.

\section{References}

Adedeji, O., Sudarkasa, M., Campbell,D.R. and Reynier, A. (2019) CTA Technical Brief: Women's Agribusiness Access Index. Technical Center for Agricultural and Rural Cooperation, Wageningen: CTA. https://cgspace.cgiar.org/bitstream/handle/10568/99706/2066_ PDF.pdf.

Adeniyi, L. (2010) Women Farmer's and Agriculture Growth: Challenge and Perspective for Africa Face the Economic Crisis. Poster presented at the Joint 3rd African Association of Agricultural Economists (AAAE) and 48th Agricultural Economists Association of South Africa (AEASA) Conference, Cape Town, South Africa.

Agarwal, B. (1994) "Gender and command over property: A critical gap in economic analysis and policy in South Asia." World Development 22(10): 1455-1478.

Agarwal, B. 2011. "Food Crises and Gender Inequality," Working Papers 107, United Nations, Department of Economics and Social Affairs.

Bhavnani, K., Foran, J. and Kurian, P. A. (2003) Feminist Futures: Re-imagining Women, Culture and Development. London: Zed Books Ltd.

Chitja, J.M., Mthiyane, C.C.N., Mariga, I.K., Shimelis, H., Murugani, V.G., Morojele, P.J., Naidoo, K. and Aphane, O.D. (2016) Empowerment of women through water use security, land use security and knowledge generation for improved household food security and sustainable rural livelihood in selected areas in Limpopo. Water Research Commission. WRC Report No. 2082/1/15. ISBN: 978-1-4312-0744-2. 
Diiro, G.M., Seymour, G., Kassie, M., Muricho, G. and Muriithi, B.W. (2018) “Women’s empowerment in agriculture and agricultural productivity: Evidence from rural maize farmer households in western Kenya." PLoS One 13(5): e0197995.

Doss, C.R., Kovarik, C., Peterman, A., Quisumbing, A.R. and van den Bold, M. (2015) Gender Inequalities in Ownership and Control of Land in Africa: Myths Versus Reality. Washington, DC: International Food Policy Research Institute.

FAO (2009) State of Food Insecurity in the World, 2009. Rome: Food and Agriculture Organization of the United Nations.

Hall, R. and Osorio, M. (2014) Agricultural Investment, Gender, and Land in Africa: Towards Inclusive Equitable and Socially Responsible Investment. Conference Report 2014. Multistakeholder Conference on Agricultural Investment, Gender and Land in Africa Towards inclusive, equitable and socially responsible investment. Protea Hotel, Stellenbosch (Cape Town), South Africa, 5-7 March 2014 www.plaas.org.za/sites/default/files/publicationspdf/AIGLIA\%20Report_Web.pdf

Krieger, N. (2003) "Genders, sexes, and health: What are the connections - and why does it matter?” International Journal of Epidemiology 32(4): 652-657.

Lorber, J. and Farrell, S.A. eds., (1991) The social construction of gender (pp. 309-321). Newbury Park, CA: Sage.

Meinzen-Dick, R., Quisumbing, A., Behrman, J., Biermayr-Jenzano, P., Wilde, V., Noordeloos, M., Ragasa, C. and Beintema, N. (2011) Engendering Agricultural Research, Development and Extension. International Food Policy Research Institute

Mkhize, G. (2015) "Problematising rhetorical representations of individuals with disability disabled or living with disability?" Agenda 29(2): 133-140.

Mkhize, G. and Njawala, L. (2016) "Rethinking hegemonic masculinity and patriarchal privilege within heterosexual interpersonal relationships." Oriental Anthropologists 16(2).

Moser, C. (1993) Gender Planning and Development: Theory, Practice and Training. London: Routledge.

Nkemnyi, F. M., Fombu, C. Y. N., Kwobenyi, N. G., \& Mumbang, C. (2017). An Assessment of the Role of Women in Development and Poverty Alleviation in Cameroon. In I. Piot-Lepetit (Ed.), Cameroon in the 21st Century: Challenges and Prospects. Volume 2: Environment and People (pp. 219-234). New York: Nova Science Publishers, Inc.

Ntsebeza, L. (2004) "Democratic decentralisation and traditional authority: Dilemmas of land administration in rural South Africa." The European Journal of Development Research 16: 1, 71-89. doi:10.1080/09578810410001688743.

Odeny, M. (2013) Improving Access to Land and Strengthening Women's Land Rights in Africa. Paper presented at the World Bank Conference on Land and poverty, Washington, DC.

Ogunlela, Y.I. and Mukhtar, A.A., (2009) Gender issues in agriculture and rural development in Nigeria: The role of women. Humanity \& Social Sciences Journal 4(1): 19-30.

Olatunji, C.-M. P. (2013) “An argument for gender equality in Africa." CLCWeb: Comparative Literature and Culture 15(1): 9.

Rai, S. (2002) Gender and the Political Economy of Development. Cambridge, UK: Polity Press.

Schatz, E. (2011) "Female headed households contending with HIV/AIDS related hardship in rural South Africa." Health \& Place 17(2):598-605.

Sen, G. and Grown, C. (1987) Development, Crises and Alternative Visions. London. Earthscan. South African Development Community (SADC) (2018) "SADC gender policy (English)." https://www.sadc.int/files/8414/0558/5105/SADC_GENDER_POLICY_-_ ENGLISH.pdf. Accessed: 03 April 2019.

Thamaga-Chitja, J.M. (2012) "How has the rural farming woman progressed since setting of Millennium Development Goals for eradication of poverty and hunger?" Agenda 26(1): $67-80$. 
Thamaga-Chitja, J.M., Kolanisi, U. and Murugani, V. (2010) "Is the South African land reform programme, gender sensitive to women's food security and livelihoods effort?" Agenda 86: 122-134.

Thamaga-Chitja, J.M. and Morojele. P. (2014) “The context of smallholder farming in South Africa: Towards livelihood asset-building framework." Journal of Human Ecology 45(2):147-155. Tripp, A., Casimiro, I., Kwesiga, J. and Mungwa, A. (2008) “Contents.” In African Women's Movements: Transforming Political Landscapes (p.V). Cambridge: Cambridge University Press. Van Schalkwyk, J.A., Groenewald, G.C.G., Fraser, A., Obi, A. and van Tilburg, A. (2012) Unlocking Markets for Smallholder in South Africa. Wageningen: Wageningen Academic Publishers.

van Arendonk, A. (2015). The development of the share of agriculture in GDP and employment. Masters Dissertation. Wageningen University, Netherlands.

Whatmore, S. (2016) Farming Women: Gender, Work and Family Enterprise. Springer. 